\title{
Sultan al-Kamil, Emperor Frederick II and the Submission of Jerusalem
}

\author{
Maher Y. Abu-Munshar
}

\begin{abstract}
In 1229 CE, following the signing of the Treaty of Jaffa by Ayyubid Sultan al-Kamil and Emperor Frederick II, Jerusalem passed into the hands of the Crusaders who then went on to rule it for the next ten years. The aim of this article is to present a critical analysis of the historical narratives of both Muslim and non-Muslim historians who continue to interpret al-Kamil's decision to hand the holy city over to the Crusaders as an act of collaboration with them. I shall attempt to answer the following questions. Did Sultan al-Kamil really offer to give Jerusalem to Emperor Frederick II in return for his support? To what extent was al-Kamil's decision a strategic attempt to suppress the Sixth Crusade? What was the outcome of the Treaty of Jaffa? And how did Muslims and non-Muslims regard it?
\end{abstract}

Index Terms-Jerusalem, Sultan al-Kamil, emperor frederick II, the sixth crusade.

\section{INTRODUCTION}

Jerusalem has a special place in the hearts and minds of the followers of Judaism, Christianity and Islam. During the course of its history, the followers of these religions have gone to considerable lengths to conquer it by any available means and at any cost. On Friday 27 Rajab 583 AH/2 October 1187 CE and after almost 88 years of occupation, Sultan Salah al-Din liberated Jerusalem from the Crusaders.[1] In 1193 CE, when Salah al-Din died, he was comfortable in the knowledge that he had realized his aim to liberate the city and assured that his successors would safeguard his achievement. Moreover, he was confident that the efforts he and other Muslims had made to liberate Jerusalem would not be lost and would ensure that henceforth only Muslims ruled the city. Unfortunately, his hopes were shortlived and Jerusalem once again fell into Crusader hands when the Ayyubid Sultan al-Kamil and Emperor Frederick II signed the Treaty of Jaffa in 1229 CE, thereby handing Jerusalem over to the Crusaders for ten years, five months and forty days. [2]

Both Muslim and non-Muslim historical literature contains a range of explanations for why al-Kamil may have been persuaded to return Jerusalem to the Crusaders at a time when he was in a relatively strong position.[3] Interestingly, these sources show negative reactions from Muslims and non-Muslims alike towards the agreement between al-Kamil and Frederick and its consequences.[4] Furthermore, a number of historians thought that al-Kamil underestimated the importance of Jerusalem in the Muslim consciousness and its strategic significance to the Ayyubid state. As Little, [5] for example, claimed, 'but once safely back in Muslim hands, interest in Jerusalem again dropped; the simple fact soon emerged that Jerusalem was not

Manuscript received May 15, 2013; revised July 10, 2013.

Maher Y. Abu-Munshar is with the Qatar University, Qatar (e-mail: m.abumunshar@qu.edu.qa). essential to the security of an empire based in Egypt or Syria.' Along the same lines, Hillenbrand argued that 'the fact of the matter was that strategically Jerusalem was not crucial to [an] Ayyubid ruler whose power base was in Egypt or Syria. Jerusalem always had its political price so long as the Franks still desired to possess it.' [6]

In this article, I aim to present a critical analysis of the historical narratives of Muslim and non-Muslim historians who continue to accuse Sultan al-Kamil of collaborating with the Crusaders by handing the Holy City over to them. Contrary to the claims of most Muslim and non-Muslim historians, I shall try to prove that al-Kamil's decision to hand over Jerusalem was part of a strategy to protect the city itself rather than to underestimate its importance to Muslim hearts and minds. In this article I shall also look at the circumstances under which al-Kamil agreed to surrender Jerusalem. I shall attempt to answer the following questions. Why did Sultan al-Kamil approach Emperor Frederick II in particular and promise to give him Jerusalem in return for his support? Can we consider al-Kamil's decision to hand Jerusalem over to Frederick as a strategic attempt to stop further campaigns by the Crusaders? In other words, by taking this step, did al-Kamil succeed in stopping the Crusaders going to Egypt, the gateway to Jerusalem? What was the outcome of the Treaty of Jaffa and how did Muslims and non-Muslim at that time regard that treaty?

\section{The Ayyubid State After Salah Al-Din}

Shortly before his death in 1193 CE, Sultan Salah al-Din divided the territories of his kingdom among his relatives; he assigned the most important and strategic regions and cities to some of his sons, and the less important ones to his brothers and remaining sons. [7] By entrusting his sons with the most important areas, including Jerusalem, which in one way or another they had helped him to liberate, historians interpreted Salah al-Din's act as a way of protecting the state. Sadly, we read that shortly after Salah al-Din's death there were quarrels over his territory and sovereignty and these caused internal friction among the Ayyubids. In other words, the unity and loyalty that Salah al-Din had been able to nurture in the Ayyubids diminished on his death. [8]

His relatives, and these included his sons and brothers, waged wars among themselves as each tried to wrench as much territory as possible from the other. [9] This created deep divisions between Salah al-Din's heirs, weakened the state and paved the way for the Crusaders' return to Jerusalem, especially given that, at various points, some of Salah al-Din's heirs approached the Crusaders for help against other members of the Ayyubid family. For example, Sultan al-Kamil offered Jerusalem to Emperor Frederick II 
in return for the latter's help and support against al-Kamil's brother al-Mu'azzam Issa, while al-Mu'azzam sought Khwarizm's help against al-Kamil. [10]

Interestingly, in $624 \mathrm{AH} / 1227 \mathrm{CE}$, shortly before Emperor Frederick II's arrival in Acre, al-Mu'azzam Issa died. [11] Logically, there was then no need for Emperor Frederick to come to the east because the al-Mu'azzam threat ended on his death. Moreover, al-Nasir Dawud, al-Mu'azzam Issa's son and successor, was in too weak a position to pose any real threat to al-Kamil. Nevertheless, al-Kamil embarked on the long journey, signed the Treaty of Jaffa in 1229 CE [12] and ceded Jerusalem to Emperor Frederick.

\section{EGYPT IN THE EYES OF THE CRUSADERS}

After the Third Crusade (1189-1192 CE), there was a widespread belief in Europe that no benefit would derive from occupying Jerusalem so long as Egypt remained strong. The best course of action, therefore, would be to attack and occupy Egypt before attacking and occupying Jerusalem. The first opportunity to implement this plan arose during the Fourth Crusade (1202-1204 CE) when the intention was to seize Jerusalem from the Muslims through invading Egypt. In fact, the plan was not achieved because, in April $1204 \mathrm{CE}$, instead of invading Egypt, the Crusaders attacked and occupied Constantinople, the capital of the Byzantine Empire. [13] A few years later, however, the goal was reasserted during the fourth Lateran Council held in 1215 $\mathrm{CE}$ in the Lateran Palace in Rome and convoked by Pope Innocent III.[14] Among the council's aims was to recover Jerusalem and 'eliminate from the Holy Land the filth of the pagans.' [15] Consequently, to implement the decisions of the above council, the Fifth Crusade (1217-1221 CE) was launched with Egypt as the target. [16] Therefore, it is clear that the ostensible purpose of the Fifth Crusade was to facilitate the capture of Jerusalem by attacking the seat of Muslim power in Egypt (Little 1990: 182). Interestingly, it seems that Muslim historian Ibn Wasil (d. 697 AH/1298 CE) was well aware of the Crusaders' new intention. He clearly stated that the wise men among the Crusaders insisted on occupying Egypt as a first step towards occupying Jerusalem. Quoting the Crusaders, he said that 'Salah al-Din was able to seize cities and towns, and to wrest Jerusalem and the Syrian coast from the Crusaders only after he controlled Egypt. Therefore, for the Crusaders' great benefit, Egypt must be under their control, so they can seize Jerusalem and other places easily.' [17]

Despite the Crusaders' great efforts to occupy Egypt as a precursor to taking Jerusalem from the Muslims, they achieved nothing but failure during the Fifth (1217-1221 CE) and Seventh (1248-1254 CE) campaigns. In both, the Crusaders' armies were defeated on Egyptian soil. [18]

\section{JERUSALEM BETWEEN AL-KAMIL AND FREDERICK} II

Interestingly, al-Kamil was able to defeat the army of the Fifth Crusade with the help of his brothers al-Mu'azzam Issa and al-Ashraf Khalil. Clearly, the victory was only achieved because of the unity and collaboration between the brothers. Unfortunately, a few years later, a power struggle emerged between al-Kamil, who sought help from Emperor Frederick II, and al-Mu'azzam Issa, who turned to the Khawarizm.

A contemporary historian, Ibn Wasil, reported an account of the negotiations between al-Kamil and Frederick in his book Mufaraj al-Kurub. The following is an extract from it:

'He who went to and from on embassies between him (alKamil) and the king-Emperor was the Amir Fakhr al-Din Ibn Al-Shaykh, and discussion on various matters went on between the two of them. In the meantime the Emperor sent al-Malik al-Kamil questions of philosophy and difficult questions on geometry in order to test his men of learning thereby. So al-Malik al-Kamil passed the arithmetical questions he has sent him to Shaykh 'Alam al-Din Qaysar Ibn Abi al-Qasim, who was foremost in this discipline. He passed the rest to a company of eminent scholars.' [19]

From Ibn Wasil's report above, it seems that negotiations between Amir Fakhr al-Din and Emperor Frederick went well from the start. This is clear from the nature of the questions the emperor sent to al-Kamil about philosophy and other scientific matters. It seems also that the emperor was happy with al-Kamil's offer and therefore could turn to ask questions about things in which he was interested.

As mentioned earlier, by the time the emperor arrived in Acre, a new development had already taken place, namely al-Mu'azzam's death in $1227 \mathrm{CE}$. This negated the need for Emperor Frederick's help, but he had already arrived. At this point, al-Kamil could have withdrawn his agreement and refused to hand Jerusalem over to the emperor. AlKhatib [20] argued that withdrawing the agreement or even starting a war against the emperor and his men would have turned al-Kamil into a hero of Islam. Why then did al-Kamil still agree to yield Jerusalem to Frederick? To answer this question, it is necessary to point out that, because of the change in circumstances on the Ayyubid side, al-Kamil had in fact tried to cancel his agreement with the emperor and had informed him of this decision. However, Muslim and non-Muslim historians concur that Frederick was unhappy about al-Kamil's change of heart and had started writing to him to persuade him to change his mind. Ibn al-'Imad al-Hanbali reported that the Emperor sent the following letter to al-Kamil:

'You have corresponded with me about my coming, and the Pope and the other kings of the West are acquainted with my zeal and my goals. But Jerusalem is the root of their belief and the goal of their pilgrimage. The Muslims have destroyed it; therefore for them it has no economic significance. If the sultan, may God strengthen him, could decide to confer on me the capital of the land with the right to visit the other Holy places. This would show his wisdom and I would raise my head among other kings.' [21]

Later on, Ibn Wasil reported that the emperor had issued an important statement to Fakhr al-Din, which read as follows:

'If I did not fear losing my respect among the Franks I would not have burdened the Sultan with such. For myself personally, neither Jerusalem nor anything else in Palestine is a goal worth struggling for. However, I must preserve my standing among them.' [22]

With continual prompting from the emperor, al-Kamil 
apparently began to recall the internal conflict among the Ayyubids and their inability to form a united front in Syria and Egypt. He then assured himself that, with this bad situation on the Muslim side, he would be unable to cope with a Crusader army within his territories.[23] Therefore, he decided to come to a peace agreement with the emperor and, in $626 \mathrm{AH} / 1229 \mathrm{CE}$, the two leaders signed the Treaty of Jaffa. In it, Sultan al-Kamil agreed to hand over Jerusalem for ten years, with Muslims denied access to all but the al-Aqsa enclave (the site of the city's sacred locations), which was to remain in Muslim hands and where Muslim religious observances would be allowed to continue unobstructed. [24]

Little looked at al-Kamil's reasons for surrendering Jerusalem from a different angle and came to the conclusion that they were the same as those that had led al-Mu'azzam Issa to dismantle its walls in $616 \mathrm{AH} / 1219 \mathrm{CE}$. The seat of alKamil's kingdom was in Egypt. For him, Jerusalem in Crusader hands without fortifications would present no threat to Egypt and would satisfy the Crusaders' apparent goals. Moreover, Little claims that Frederick was characteristically Crusader like, even cynical, in pointing out these factors to al-Kamil. [25]

\section{EMPEROR FREDERICK II IN JERUSALEM}

Historical literature provides us with a comprehensive picture of the incidents of that time. Ibn Wasil, for example, was one of those historians who made his report on what had taken place immediately after al-Kamil and Frederick singed the peace treaty. He wrote that:

'When the matter of the truce was concluded, the Emperor sought leave of the Sultan to visit Jerusalem. Leave was granted to him, and the Sultan commissioned the judge Shams al-Din, the judge of Nablus, a man of eminence in the state and in high honour with the Ayyubid Kings, to attend on the Emperor until he had visited Jerusalem and retuned to Acre. Shams al-Din told me [Ibn Wasil] saying, "when the emperor came to Jerusalem, I attended on him as the Sultan al-Malik al-Kamil had commanded me, and I entered the al-Aqsa enclave with him, and he saw the places of pilgrimage [worship] in it." Then I entered the Aqsa Mosque with him, and its construction and the construction of the Dome of the Rock delighted him. When he reached the mihrab [niche] of the Aqsa, its beauty and the beauty of the pulpit delighted him. He went up the stairs to the top. Then he came down, and took my hand, and we came out of the al-Aqsa. He saw a priest with the gospels in his hand, who wanted to enter the al-Aqsa, so he shouted disagreeably to him, "what's that you have brought here? By God, if one of you tries to get in here without my leave, I will have his eyes out. We are the vassals and slaves of this sultan al-Malik al-Kamil. He has granted these churches to me and to you as an act of grace. Do not any of you step out of line." The priest made off shaking with fear.'[26]

The above statement by Ibn Wasil is very important because it gives us a first-hand report of what happened in Jerusalem during the emperor's first ever visit. Moreover, it shows the emperor's attitudes to Islam and Muslim holy places. In fact, this report will be very useful later on when I discuss the reasons why al-Kamil chose Frederick II for the above mentioned task over and above any other Christian king or leader.

\section{REACTIONS TO THE AL-KAMIL-FREDERICK AGREEMENT}

As one might expect, the Treaty of Jaffa was unpopular in the Muslim world. On learning that Jerusalem was back in Christian hands, Muslims predictably felt intense emotions. [27] Well-known historian Sibt Ibn al-Jawzi reported that the news of the handing over of Jerusalem to the Crusaders was received with widespread anger and outrage amongst Muslims in all the lands of Islam.'[28] Moreover, Sibt Ibn al-Jawzi added 'that al-Nasr Dawud, the ruler of Damascus, asked him to speak in the great mosque [Ummayed Mosque] about what had happened to Jerusalem and he waxed lyrical about the recent indignities the city had suffered.' [29]

Pernoud assessed the outcomes of this treaty in an interesting way. He argued that although the Crusaders achieved their aim, this peace agreement had in fact satisfied no one, neither Muslims nor Crusaders. He quoted the historian al-Maqrizi who said that:

'The sultan al-Kamil was unanimously blamed for having acted thus and his conduct was severely judged throughout the country. As for the Christians, Pernoud claimed that they blamed the treaty of Jaffa for having left undecided the essential points, that [of] the restoration of the walls of the holy city. He justified his claim by staying that "in the following year, the soundness of this approach was proved by a raid which caused much causality among the population of Jerusalem, who had been left without defence against the incursion of pillages".' [30]

\section{AL-KAMIL's JUSTIFICATIONS}

On learning of the Muslims' widespread anger and outrage over the Treaty of Jaffa, al-Kamil tried to justify his act by minimizing its negative impact on Jerusalem and listing its benefits to Muslims. Nevertheless, since Sultan al-Din's heroic regaining of Jerusalem in 1187, al-Kamil's task of trying to convince Muslims that Jerusalem should be voluntarily traded away forty-two years later was by no means an easy one. The historian Ibn Wasil set out some of al-Kamil's justifications, claiming that al-Kamil said:

'We have allowed only ruined churches and monasteries. The al-Aqsa enclave and what is in it consisting of the Dome of the Rock and the rest of shrines are in the hands of the Muslims as before and the sign of Islam is on what is there [al-Aqsa enclave]. [31] Furthermore, to support his case, al-Kamil explained that Jerusalem had no fortification to stand against any Muslim attack, and it would easily be recomputed at a later date. [32]

Commenting on al-Kamil's above justifications, Hillenbrand agreed that Muslims would easily be able to conquer such a defenceless city at a later date. She added that, with al-Kamil's power base in Egypt, a Jerusalem bereft of defences would present no threat to him. Therefore, Jerusalem could be handed over to the Crusaders who wanted it 
as part of a treaty that ensured that Egypt would be left alone. [33] Now, the question that arises here is, in handing Jerusalem over to Frederick, did Sultan al-Kamil understate the city's religious significance to Muslims? Hillenbrand tried to answer this question by arguing that al-Kamil signed the treaty with Frederick out of political expediency. She further argued that the sultan feared hostilities from other Ayyubids in Syria, such as al-Mu'azzam Issa, so needed the Crusaders' military support. She concluded by saying that, for al-Kamil, Jerusalem formed part of the deal and its religious status was far from uppermost in his mind. [33]

Although Muslims find is difficult to accept al-Kamil's action, I nevertheless disagree with Hillenbrand. I would like to argue that there is no doubt that al-Kamil was fully aware of the importance of Jerusalem to Muslims; also, he was aware of the hard and complicated steps that Salah al-Din had taken to liberate it from the Crusaders. [32] Moreover, he was sure of the Crusaders' ostensible reason, which was to facilitate the capture of Jerusalem by attacking and occupying Egypt. Unfortunately, with the dispute between al-Kamil and his brothers, and the absence of unity among Muslims, Egypt would sooner or later fall victim to a Crusader campaign. I shall argue that selecting Emperor Frederick to carry out this task in exchange for Jerusalem was not hatched in a vacuum, but inspired by many factors:

- Frederick's tolerant attitude towards Muslims and Arabs as a result of having grown up within them in Sicily. In addition, he was fluent in Arabic and responsive to Arab and Muslim culture. This is evident when Frederick entered the al-Aqsa enclave and showed his respect for Islamic rituals. We saw that in Ibn Wasil's report above. [34]

- The attitude of Frederick towards Pope Gregory IX and the latter's decision to excommunicate him for his indirect refusal to participate in the Fifth Crusade. [35] So, al-Kamil was trying to exploit this dispute between the two men.

- Al-Kamil was sure that sooner or later a new Crusader campaign would arrive in the east because of the failure of the Fifth Crusade. Moreover, al-Kamil was aware that Emperor Frederick II, under pressure from the pope, was planning a Sixth Crusade.

- By concluding the Treaty of Jaffa, al-Kamil was able to delay any future Crusade for more than ten years. These ten years were long enough to allow him to build up a strong army. This was later proved when the army of al-Kamil's son (Najm al-Din) defeated that of the Seventh Crusade and captured its leader, King Louis IX. [36]

\section{CONCLUSION}

To conclude, contrary to the claims of most Muslim and non-Muslim historians, I argue that al-Kamil's decision to hand Jerusalem over was part of a strategy to protect the city rather than a failure to recognize its significance in the hearts and minds of Muslims. In other words, by taking this step al-Kamil succeeded in discouraging the Crusaders from going to Egypt, their prime target and the key to Jerusalem.
Interestingly, quoting Cahen and Chabbouh, Little recounts Sultan Najm al-Din Ayyub's advise to his son Turanshah on the eve of the Seventh Crusade:

'If you unable to contain the God forsaken enemy and they march out of Damietta against you [in Cairo] and, if you lack power to cope with them and help fails to reach you in time, and they demand from you the cost [of Palestine] and Bait al-Maqdis, give these places to them without delay on condition that they have no foothold in Egypt.' [37]

Along the same lines, we know that, at the time of the Fifth Crusade, Sultan al-Kamil and his brother al-Mu'azzam Issa had offered to surrender Jerusalem and many other places, with the exception of al-Karak and al-Shawbak (in Sothern Jordan), if the Crusaders agreed to leave Egypt. However, the Crusaders led by the papal legate Pelagius, refused to accept these terms in the hope that they would win the battle and take Egypt from the Ayyubids. Finally, Sultan Najm al-Din's advice to his son (cited above) and the brothers' offer to Crusaders of the Fifth Crusade clearly showed that Egypt must not fall into Crusader hands. This is because, if the Muslims lost Egypt, they would definitely also lose Jerusalem.

\section{REFERENCES}

[1] B. A. Asali, Al-Ayyam al-Hasima fi al-Hurub al-Salibiyya, Beirut: Dar al-Nafa'is, 1978, pp. 130.

[2] I. Y. A. Khatib, al-Quds Bayn Atma Al-Salibiyyn wa Tafrit al-Malik al-Kamil al-Ayyubi, Amman: Dar al-Manahij lilnashr wa al-Tawzi, 2001, pp. 288-289.

[3] N. Jubran and M. H. A. Amadi, Dirasat fe Tarikh al-Ayyubiyin wa alMamalik, Irbid-Jordan: Mu'assasat Hamada Lidirasat al-Jami'iya wa al-Nashr, 2000, pp. 159-162.

[4] A. A. Sallabi, Al-Ayyubiyun Ba'd Salah al-Din: Al-Hamalat alSalibiyya al-Rabi 'a, al-Khamisa, al-Sadisa wa al-Sabi 'a, Beirut: Dar al-Ma'rifa, 2009, pp. 297-299.

[5] D. P. Little, "Jerusalem under the Ayyubids and the Mamluks 11871516 AD," in K. J. Asali, Ed. Jerusalem in History, New York: Olive Branch Press, 1990, pp. 181.

[6] C. Hillenbrand, The Crusades: Islamic Perspectives, Edinburgh: Edinburgh University Press, 2006, pp. 221.

[7] Jubran and A. Amady, Dirasat fe Tarikh al-Ayyubiyin, op. cit., pp. 134-135.

[8] Little, "Jerusalem under the Ayyubids and the Mamluks 1187-1516 AD," op. cit., pp. 209.

[9] Jubran and A. Amady, Dirasat fe Tarikh al-Ayyubiyin, op. cit., pp. 136-206.

[10] A. Khatib, al-Quds Bayn Atma 'Al-Salibiyyn, op. cit., pp. 271-279.

[11] J. I. Wasil, Mufarij al-Kurub fi Akhbar Bani Ayyub, Cairo: n.p., n.d., vol. 4. pp. 204.

[12] J. Phillips, Holy Warriors: A Modern History of the Crusades, London: Vintage Books, 2010, pp. 234.

[13] Phillips, Holy Warriors, op. cit., pp. 190-196.

[14] Phillips, Holy Warriors, op. cit., pp. 206.

[15] Phillips, Holy Warriors, op. cit., pp. 166.

[16] A. Da'kur, Al-Dawla al-Ayyubiya Tarikhuha al-Siysi wa al-Hadari, Beirut, Dar al-Mawasim, 2006, pp. 189.

[17] J. I. Wasil, Mufarij al-Kurub, Cairo: al-Matba'a al-Amiriyya, 1957, vol. 3 , pp. 256.

[18] A. Sallabi, Al-Ayyubiyun Ba'd Salah al-Din, op. cit., pp. 169, 367.

[19] I. Wasil, Mufarij al-Kurub, op. cit., vol. 4. pp. 626, English translation of this text was taken from P. M. Holt, The Age of the Crusades: The Near East from Eleventh Century to 1517, London: Longman Group Limited, 1986, pp. 65.

[20] A. Khatib, al-Quds Bayn Atma'Al-Salibiyyn, op. cit., pp. 302.

[21] I. A. Hanbali, Shatharat al-Dhahab fi Akhbar man Dhahab, Berut: Dar al-Masira, English translation of this text has been taken from Little, "Jerusalem under the Ayyubids and the Mamluks 1187-1516 AD,” op. cit., vol. 5, pp. 183, 1979.

[22] I. Wasil, Mufarij al-Kurub fi Akhbar Bani Ayyub, op. cit., vol. 4, pp. 243, English translation of this text has been taken from Little, 
"Jerusalem under the Ayyubids and the Mamluks 1187-1516 AD," op. cit., pp. $183-184$.

[23] Little, "Jerusalem under the Ayyubids and the Mamluks 1187-1516 AD," op. cit., pp. 184.

[24] Hillenbrand, The Crusades, op. cit., pp. 216-217.

[25] Little, "Jerusalem under the Ayyubids and the Mamluks 1187-1516 AD," op. cit., pp. 183.

[26] I. Wasil, Mufarij al-Kurub, op. cit., vol. 4. pp. 244-245, English translation of this text has been taken from Holt, The Age of the Crusades, op. cit., pp. 65.

[27] A. Khatib, al-Quds Bayn Atma 'Al-Salibiyyn, op. cit., pp. 294-295.

[28] S. I. A. Jawzi, Mir'at al-Zaman fi Tarikh al-A 'yan, India: Matba't Majlis Dar al-Ma'arif bihaydar Abad, vol. 8, no. 2. pp. 654.

[29] S. I. A. Jawzi, Mir'at al-Zaman, vol. 8, no. 2, pp. 654.

[30] R. Pernoud, The Crusades, translated by E. MacLeod, London: Secker \& Warburg, 1962, pp. 231.

[31] I. Wasil, Mufarij al-Kurub, op. cit., vol. 4. pp. 244-245, English translation of this text was taken from Hillenbrand, The Crusades, op. cit., pp. 216-217.

[32] I. Wasil, Mufarij al-Kurub, op. cit., vol. 4. pp. 243.

[33] Hillenbrand, The Crusades, op. cit., pp. 217.

[34] I. Wasil, Mufarij al-Kurub fi Akhbar Bani Ayyub, op. cit., see also Phillips, Holy Warriors, op. cit., vol. 4, pp. 235.

[35] N. Housley, The Crusaders, Stroud, Gloucestershire: Tempus Publishing Ltd, 2002, pp. 103.

[36] I. Wasil, Mufarij al-Kurub, op. cit., vol. 4. pp. 247; see also, AlSallabi, Al-Ayyubiyun Ba'd Salah al-Din, op. cit., pp. 267-268.

[37] Little, "Jerusalem under the Ayyubids and the Mamluks 1187-1516 AD," op. cit., pp. 186

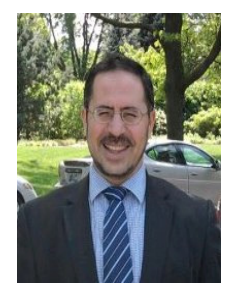

Maher Abu-Munshar was born in Hebron, Palestine (1970). He is an assistant Professor of Islamic History at Qatar University. In 2003 he completed a Ph.D. in Islamic History (Dundee, UK). In 2008, he was awarded a Postgraduate Certificate in Teaching in Higher Education (Pg CertTHE) by Dundee University, UK. Prior to joining Qatar University, he was a visiting Senior Lecturer in the Department of Islamic History and Civilization at the University of Malaya-Malaysia and before that he worked as a Lecturer at the Al-Maktoum Institute (University of Aberdeen, UK) from 2003 to 2009. His teaching and research expertise lies in Islamic history, with a special interest in the histories of Jerusalem, of Muslim-Christian relations and of the Crusades. He is author of Islamic Jerusalem and its Christians: A History of Tolerance and Tensions (I.B.Tauris, 2007 and 2013) as well as many articles on different aspects of Jerusalem, Islamic history, Christian-Muslim relations and the study of Islam and Muslims. His most recent articles are "Fatimids, Crusaders and the fall of Islamic Jerusalem: Foes or Allies?" Al-Masaq: Islam and the Medieval Mediterranean Journal (Routledge) April 2010; the "Compatibility of Islam with Pluralism: Two Historical Precedents", Journal of Islam and Civilisational Renewal (Pluto Journals) July 2010, "Orientalists and Israeli Scholars' Portrayal of Muslim Treatment of non-Muslims in Islamicjerusalem", Journal of Islamicjerusalem Studies (July 2011) and "In the Shadow of the 'Arab Spring': the Fate of Non-Muslims under Islamist Rule", Islam and Christian-Muslim Relations, vol. 23 (4), October 2012 (Routledge). In addition, as a mark of recognition for his scholarly work, he was elected a fellow of the Higher Education Academy (UK) in May 2008 and a fellow of the Royal Historical Society (UK) in April 2009. 